\title{
Modulating cGMP to Treat Lung Diseases
}

\author{
Hossein-Ardeschir Ghofrani and Friedrich Grimminger
}

\section{Contents}

1 Adaptation of Blood Flow to Ventilation in the Pulmonary Circulation . . . . . . . . . 470

2 Proof of Principle: NO-Inhalation to Improve Gas Exchange in Acute Lung Failure . . . . 470

3 PDE5 in the Pulmonary Circulation: Gateway Opener for Oral Therapy . .......... 471

4 Clinical Experience with Sildenafil for the Treatment of Chronic

Pulmonary Hypertension . . . . . . . . . . . . . . . . . . . . . . . . . 473

5 Pivotal Trial and Approval of Sildenafil for the Treatment of PAH (SUPER-1) . . . . . 475

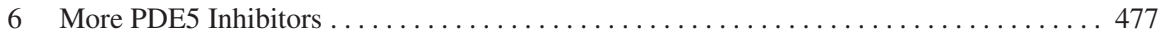

7 Soluble Guanylate Cyclase: A New Target for the Treatment of Pulmonary

Vascular Disorders . . . . . . . . . . . . . . . . . . . . . . . . . . . . . 478

References ................................................. 479

Background: Nitric oxide (NO) is constitutively produced in the lung by NOsynthases. The main cellular sources of lung NO production are the vascular endothelium and the airway epithelia (Bohle et al. 2000; German et al. 2000; Ide et al. 1999). Local NO production contributes to regulation of pulmonary perfusion depending on alveolar ventilation to assure optimized ventilation/perfusion distribution (Grimminger et al. 1995). NO-synthase activity is regulated on transcriptional and post-translational redox-based modulation level. The common signaling pathway of endogenous vasodilators, such as nitric oxide, prostaglandins, and natriuretic peptides, engage cyclic nucleotides (cAMP and cGMP). These second messengers are mainly produced by activation of adenylate- and guanylate-cyclases, both membrane-bound and soluble (Beavo 1995). Phosphodiesterases (PDEs) represent a superfamily of enzymes, with PDE1 through PDE11 being currently known, that inactivate cyclic AMP and cyclic GMP, with different tissue distribution and substrate specificities (Ahn et al. 1991; Von Euler and Liljestrand. 1946). Because of stabilization of these second messengers, PDE inhibitors differentially regulate levels of cAMP and/or cGMP, depending on their selectivity profile. Recently, direct

H.-A. Ghofrani (凶)

University Hospital Giessen and Marburg GmbH, Klinikstrasse 36, 35392 Giessen, Germany ardeschir.ghofrani@innere.med.uni-giessen.de

H.H.H.W. Schmidt et al. (eds.), cGMP: Generators, Effectors and Therapeutic Implications, 469 Handbook of Experimental Pharmacology 191,

(c) Springer-Verlag Berlin Heidelberg 2009 
activators and stimulators of the sGC have been suggested as new therapeutic tools for the treatment of lung vascular disorders that might have even higher potency than PDE inhibitors or exogenously applied NO.

\section{Adaptation of Blood Flow to Ventilation in the Pulmonary Circulation}

Adaptation of perfusion to ventilation is one of the most important features of pulmonary physiology. The key regulator of this phenomenon is hypoxic vasoconstriction, a reflex originally described by von Euler and Liljestrand (Von Euler and Liljestrand. 1946), which ensures optimized gas exchange (Grimminger et al. 1995; Weissmann et al. 2001). As changes in the distribution of blood flow to different areas of the lung must occur rapidly (e.g., when changing from prone to supine position, or when stressing the pulmonary circulation upon exercise), adjustments of vessel diameter in the respective regions of the lung must be regulated immediately (Cohen et al. 1996; Hillier et al. 1997). A key molecule for this fast response, which links alveolar ventilation (and thus the degree of regional oxygenation) to local lung perfusion, is nitric oxide (NO): it has been conclusively shown that the fall in lung NO production precedes the rise in pulmonary pressure upon induction of acute experimental hypoxic pulmonary vasoconstriction (HPV), as well as that lung NO production is closely related to the degree of alveolar ventilation (Weissmann et al. 2000).

\section{Proof of Principle: NO-Inhalation to Improve Gas Exchange in Acute Lung Failure}

The adult respiratory distress syndrome (ARDS) is characterized by gas exchange disturbances as a result of (1) loss of alveolar-capillary barrier integrity, with reduced diffusion capacity, (2) increases in ventilation/perfusion mismatch, and (3) acute pulmonary hypertension (Radermacher et al. 1989; Melot et al. 1989). Several attempts have been undertaken to improve gas exchange with systemically applied vasodilators, which resulted in reduction of pulmonary hypertension, but were hampered by concomitant worsening in gas exchange (Rossaint et al. 1993). Inhaled nitric oxide administered in patients with ARDS could for the first time display features of a vasodilator that selectively dilates vessels in the lung (pulmonary selectivity), and in addition preferentially dilates vessels in well ventilated areas only (intrapulmonary selectivity) (Fig. 1) (Schermuly et al. 2000). Improvements in oxygenation in this patient collective were attributed to a reduction in intrapulmonary shunt-perfusion. In contrast, infused prostacyclin - although potently reducing pulmonary pressure - had no selectivity for the pulmonary circulation (i.e., equipotently reduced systemic vascular resistance) and in addition resulted in deteriorated 


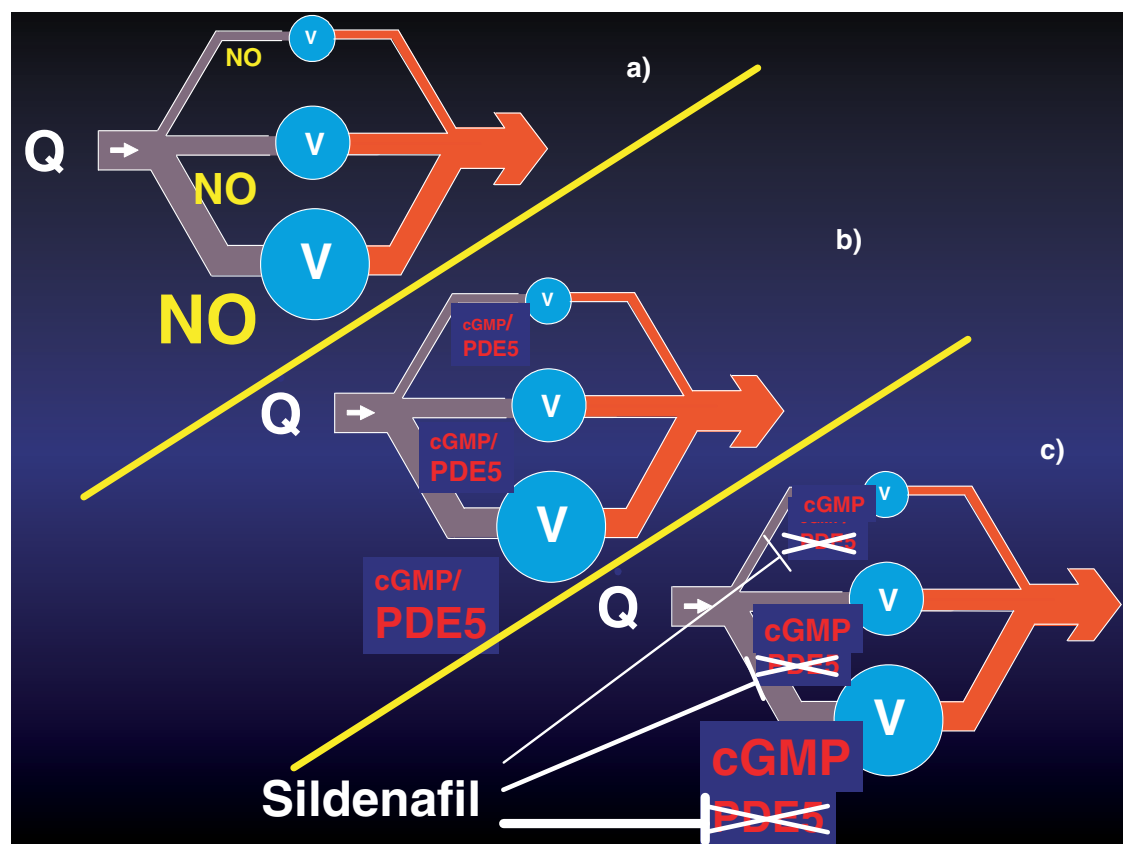

Fig. 1 Rationale for intrapulmonary selective vasodilatation by sildenafil. Nitric oxide (NO) is released in the lung, preferentially in well ventilated areas of the lung (V) and thus directs blood flow (Q) into these regions by local vasodilatation. In contrast, in regions with less ventilation, only little NO is produced and resistance vessels in these regions constrict due to hypoxic pulmonary vasoconstriction reflex (a). In areas with high local NO production, more cGMP is released as a second messenger of NO-response and concomitantly PDE5 activity is upregulated. Again only little PDE5 activity is present in areas of less ventilation (b). The PDE5 inhibitor sildenafil, despite systemic administration, preferentially acts in areas of good regional ventilation, thereby augmenting the endogenous vasodilatory action of NO redirecting blood flow optimizing ventilation/perfusion matching (c)

oxygenation by worsening of ventilation/perfusion matching. However, only few reports support the long term treatment of chronic pulmonary hypertension by continuous therapy with NO inhalation (Channick et al. 1996; Higenbottam et al. 2000).

\section{PDE5 in the Pulmonary Circulation: Gateway Opener for Oral Therapy}

In patients with idiopathic pulmonary arterial hypertension (iPAH), intravenous prostacyclin has been demonstrated to be a potent pulmonary vasodilator, and long-term infusion of this prostanoid was found to improve exercise tolerance and survival in these patients (Egan 1999). However, in the presence of ventilatory disorders, systemic administration of vasodilators regularly increases the blood flow to low or nonventilated lung areas by interfering with the physiological 
hypoxic vasoconstrictor mechanism, thereby worsening preexistent ventilation(V)/perfusion(Q) mismatch and shunt flow (Agusti and Rodriguez-Roisin 1993; Olschewski et al. 1999). Decrease in arterial oxygenation and wasting of the small ventilatory reserve of these patients are the disadvantages of this effect. Inhalation of a vasorelaxant agent to achieve selective pulmonary vasodilation and to redistribute blood flow to the well-ventilated lung areas is an appealing concept to circumvent these hazards (Walmrath et al. 1993; Olschewski et al. 1996). In pulmonary arterial hypertension, daily repetitive aerosolization of the long-acting prostacyclin analogue iloprost has been suggested as a new therapeutic concept (Olschewski et al. 1996, 1998, 2000, 2002; Hoeper et al. 2000). In secondary pulmonary hypertension linked to lung fibrosis, inhaled iloprost was found to decrease the pulmonary vascular resistance similar to intravenous prostacyclin, but not to increase shunt flow as occurred during prostanoid infusion in these patients (Rubin 1997). Continuous inhalation strategies are, however, hampered by practical burdens due to the cumbersome use of inhalation devices as well as the necessity of frequent inhalations over the daytime.

Phosphodiesterases are a superfamily of enzymes that inactivate cyclic adenosine monophosphate and cyclic guanosine monophosphate, the second messengers of prostacyclin and nitric oxide. The phosphodiesterases have different tissue distributions and substrate affinities (Fig. 2); in particular, phosphodiesterase-5 is abundantly expressed in lung tissue (Beavo 1995). The first oral drug to show a selective

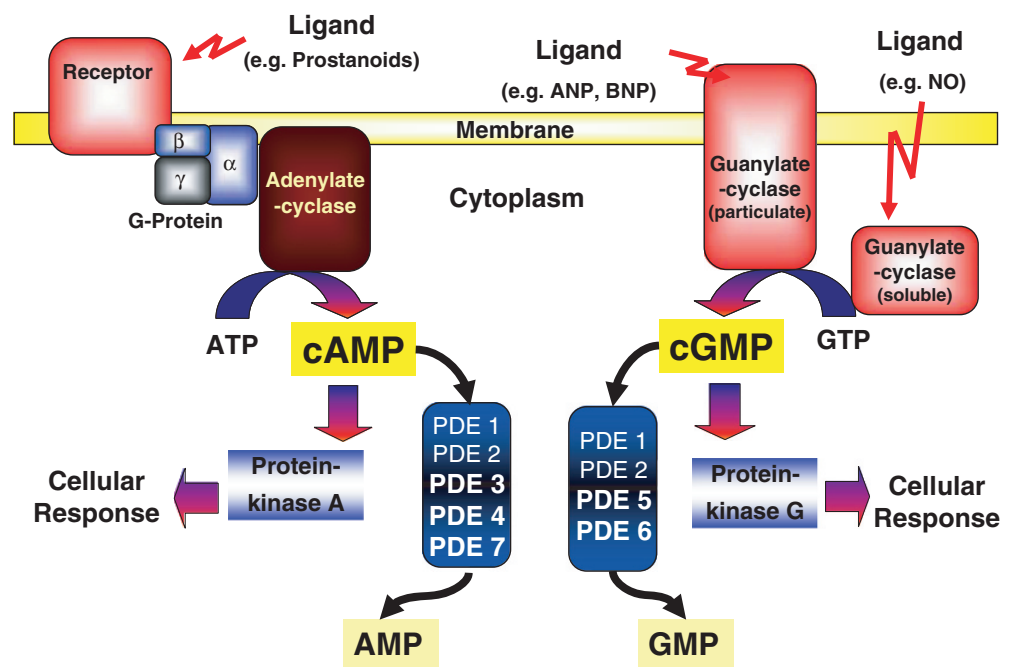

Fig. 2 Scheme of prostanoids, NO, and natriuretic-peptides activated signaling pathways. NO activates soluble- and natriuretic peptides, the membrane-bound guanylate cyclases that synthesize cyclic GMP, which subsequently activates protein kinase G. On the other hand, prostanoids activate the adenylate cyclase, increasing intracellular levels of cAMP with consecutive intracellular signaling. The downstream effects of cGMP and cAMP are limited by phosphodiesterases (PDE), some of which are selectively degrading cAMP or cGMP only, others acting on both mediators 
(preferential lung over systemic vasodilation) and "supra-selective" (vasodilation in well-ventilated, but not in nonventilated lung areas) pulmonary vasorelaxation was the phosphodiesterase (PDE) type 5 inhibitor sildenafil: In patients with lung fibrosis and concomitant pulmonary hypertension, known to be susceptible to gas exchange abnormalities due to underlying intrapulmonary shunt flow, the pharmacological properties of sildenafil were tested (Ghofrani et al. 2002b). Oral sildenafil was found to cause pulmonary vasodilation in patients with lung fibrosis and pulmonary hypertension, with an overall potency corresponding to that of intravenous prostacyclin (Fig. 3). Most notably, in contrast to the infused prostanoid, selectivity for well-ventilated lung areas was demonstrated for sildenafil, resulting in an improvement rather than a deterioration of gas exchange (Fig. 4). Controlled randomized trials, however, are needed to confirm the therapeutic benefit in this secondary form of pulmonary vascular disorder. However, this unique profile, never before disclosed for a systemically administered agent, suggested that the PDE-5 inhibitor sildenafil might be a promising candidate for long-term treatment of severe forms of pulmonary hypertension.

\section{Clinical Experience with Sildenafil for the Treatment of Chronic Pulmonary Hypertension}

A case report of a patient suffering from severe pulmonary arterial hypertension who was treated chronically with very high doses of oral sildenafil indicated that this approach might be effective (Prasad et al. 2000). In pediatric patients, the administration of intravenous prostacyclin is even more hampered by problems associated with i.v. mode of administration than in adults. A study reporting the successful use of oral sildenafil in a child with severe pulmonary hypertension attracted attention, not only within the medical community, but also in the media (Abrams et al. 2000; Patole and Travadi 2002; Oliver and Webb 2002). Trials addressing the characterization of the acute effects of sildenafil on pulmonary and systemic hemodynamics in a larger number of patients with pulmonary arterial hypertension showed that sildenafil effectively reduced pulmonary vascular resistance in a dose-dependent manner (Ghofrani et al. 2002a). In combination with a prostanoid (inhaled iloprost), augmentation of the pulmonary vasodilatory effect of each single agent was observed (Ghofrani et al. 2002a; Wilkens et al. 2001). Long-term treatment of patients with pulmonary arterial hypertension was investigated in a number of single-centre studies, all confirming the efficacy and tolerance of chronic oral sildenafil treatment (Kothari and Duggal 2002; Sastry et al. 2002, 2004). In patients with deteriorating severe PAH despite ongoing prostanoid treatment, additional long-term administration of oral sildenafil improved exercise capacity and pulmonary hemodynamics (Ghofrani et al. 2003a). Thus, the combination of prostanoids and sildenafil has potential as a possible future treatment for pulmonary hypertension. Numerous reports on the clinical use of sildenafil in pulmonary arterial hypertension in uncontrolled trials have been published to date 

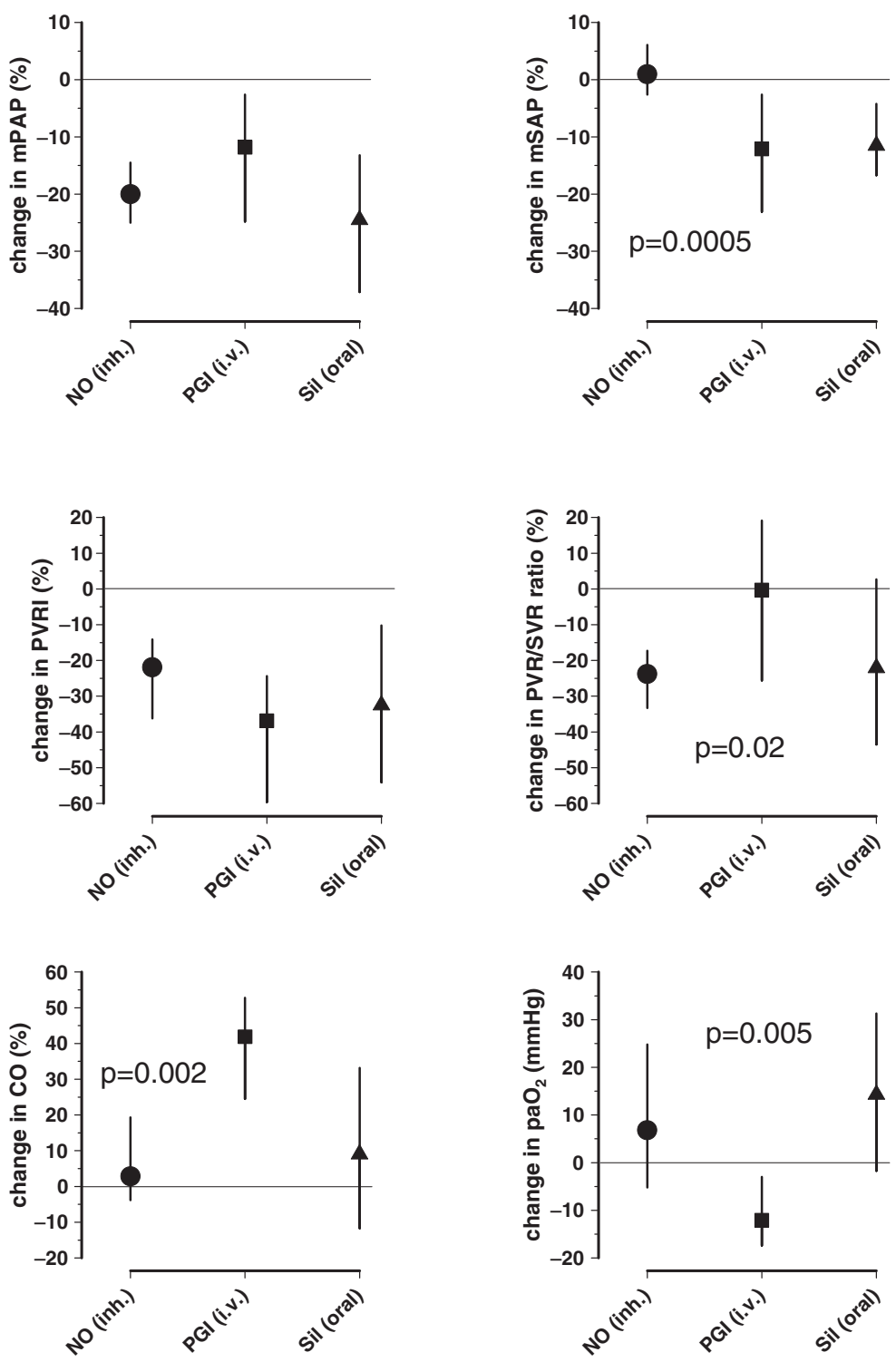

Fig. 3 Hemodynamic and gas exchange response to inhaled NO, infused $\mathrm{PGI}_{2}$, and oral sildenafil in patients with lung fibrosis and pulmonary hypertension. Deviations from preintervention baseline are displayed for inhaled NO, infused prostacyclin (PGI i.v.), and oral sildenafil (Sil oral). Abbreviations: $m P A P$ Mean pulmonary arterial pressure, $m S A P$ Mean systemic arterial pressure, $C O$ Cardiac output, $P V R I$ Pulmonary vascular resistance index, $P V R / S V R$ ratio Ratio of pulmonary to systemic vascular resistance, $\mathrm{paO}_{2}$ Partial pressure of arterial oxygen (changes given in $\mathrm{mmHg}$ ) (adapted from Ghofrani et al. 2002) 


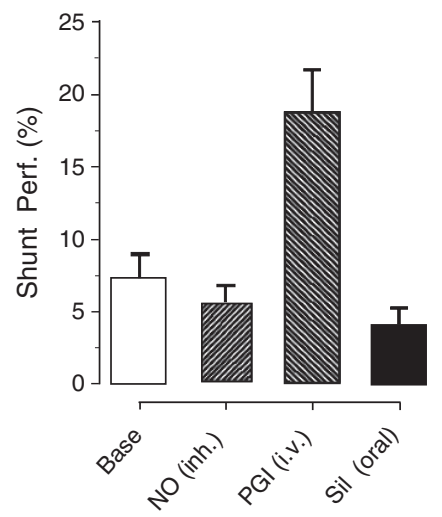

Fig. 4 Pulmonary shunt flow at baseline and in response to vasodilator challenge (assessed by MIGET). The percentage (mean $\pm \mathrm{SD}$ ) of shunt perfusion of total pulmonary blood flow is displayed at baseline (Base), during NO inhalation (NO (inh.)), during infusion of prostacyclin (PGI (i.v.)), and after oral sildenafil (Sil (oral)).

(Kothari and Duggal 2002; Sastry et al. 2002; Watanabe et al. 2002; Zimmermann et al. 2002; Singh et al. 2002; Lepore et al. 2002; Michelakis et al. 2002; Zhao et al. 2003).

Sildenafil appears to be effective for treating patients with pulmonary hypertension of diverse causes in addition to idiopathic pulmonary arterial hypertension. In patients suffering from human immunodeficiency virus (HIV)-related pulmonary hypertension, sildenafil was effective in reducing the pulmonary vascular resistance, as it was in iPAH (Schumacher et al. 2001; Carlsen et al. 2002). Recent data suggest that long-term oral sildenafil treatment in patients with nonoperable chronic thromboembolic pulmonary hypertension or portopulmonary hypertension can be beneficial (Ghofrani et al. 2003b; Reichenberger et al. 2007). The importance of this finding lies in the fact that there is little to offer as a therapeutic option for these patients, with the exception of lung transplantation.

\section{Pivotal Trial and Approval of Sildenafil for the Treatment of PAH (SUPER-1)}

A growing body of evidence from various studies between 1998 and 2001, which demonstrated the efficacy of sildenafil in the treatment of pulmonary arterial hypertension, led to the design of a large randomized, controlled, multinational trial to provide a final proof of this new treatment concept, and to obtain regulatory approval for sildenafil as a new treatment for pulmonary arterial hypertension. The SUPER-1 (Sildenafil Use in Pulmonary Hypertension) study begun in 2002 and included 278 patients with symptomatic pulmonary arterial hypertension who were treated either 


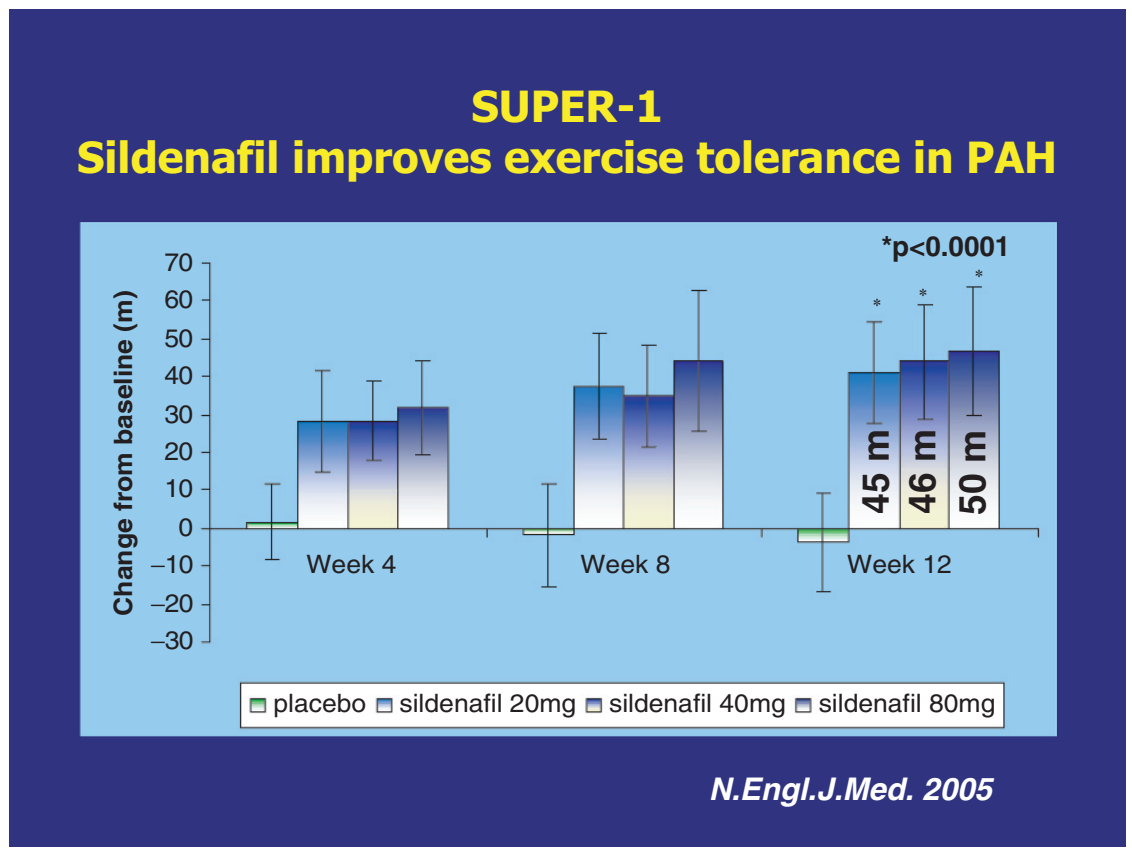

Fig. 5 Key results from the pivotal RCT with sildenafil in PAH (SUPER-1 trial). Changes in the six-minute walking distance as compared to baseline values after 4, 8, and 12 weeks, respectively, are shown in this graph. Patients received either placebo or 20,40 , or $80 \mathrm{mg}$ sildenafil TID

with a placebo or sildenafil $(20,40$, or $80 \mathrm{mg}$ ) orally, three times daily, for 12 weeks (Fig. 5). The primary end-point of this trial - as in many similar trials with other medications - was a significant improvement comparing baseline to week 12 in the 6-min walk test. Sildenafil (in all the tested doses) improved exercise capacity (up to $50 \mathrm{~m}$ (placebo corrected value) in the $80 \mathrm{mg}$ three times daily (TID) group), functional class, and hemodynamics, as compared to placebo-treated patients, and was very well tolerated (Galie et al. 2005). Additionally, patients completing the doubleblind phase were able to enter a long-term extension trial, which was conducted over a 2 -year period and received $80 \mathrm{mg}$ sildenafil TID. The increase of the 6-min walk distance achieved after 3 months in the placebo-controlled phase was maintained even after 1 year of therapy, as were the improvements in functional class, both results were strongly indicative of the maintenance of the effect despite the severity of the disease. Based on the very favorable mid- and long-term effects of this new oral treatment, sildenafil was approved by the FDA and the EMEA in 2005 for the treatment of patients suffering from PAH. Both agencies decided to approve only the $20 \mathrm{mg}$ TID dose, as only a flat (nonsignificant) dose-effect relationship between 20-80 mg TID was observed regarding the primary end-point of the study, the increase in 6-min walking distance over 12 weeks treatment. An analysis of sildenafil plasma levels in the SUPER-1 study showed no dose-effect relationship with the doses that were studied (data on file, unpublished). There is evidence from some 
clinical and experimental settings that the duration of action of sildenafil may not be accurately reflected by plasma-levels and the applied dosage (Moncada et al. 2004). It has been shown that the affinity of sildenafil to PDE5 remains increased after intracellular phosphorylation of the enzyme (Mullershausen et al. 2003). In addition, the conformational changes of PDE5 and the slow dissociation rate of sildenafil from the enzyme may contribute to the flat dose-effect relationship (Francis et al. 1998; Gopal et al. 2001; Corbin and Francis 2002; Huai et al. 2004). Another possible explanation is the hypothesis that sildenafil binding to the catalytic site of PDE5 could occur at higher affinity and may thus retard clearance of the inhibitor from the cell. On the contrary, in the SUPER-1 trial there were clear trends in some secondary endpoints (some showed statistically significant differences between the three applied doses), indicating that, for a subgroup of patients, higher doses might be more efficacious than the approved $20 \mathrm{mg}$ TID dosage. Moreover, in the majority of previous short- and long-term studies, daily doses of 100 up to $300 \mathrm{mg}$ were investigated and reported to be efficacious and well tolerated (Ghofrani et al. 2002a; Wilkens et al. 2001; Kothari and Duggal 2002; Sastry et al. 2004; Michelakis et al. 2003). Thus, future studies are warranted, addressing the long-term efficacy of $20 \mathrm{mg}$ TID or even smaller doses of sildenafil for the treatment of PAH.

\section{More PDE5 Inhibitors}

In a comparative clinical trial, 60 consecutive PAH patients (NYHA classification II-IV) undergoing right heart catheterization for acute pulmonary vasoreactivity testing received initial short-term nitric oxide inhalation and were subsequently assigned to oral intake of $50 \mathrm{mg}$ sildenafil $(n=19), 10 \mathrm{mg}(n=7)$ or $20 \mathrm{mg}(n=9)$ vardenafil, or $20 \mathrm{mg}(n=9), 40 \mathrm{mg}(n=8)$, or $60 \mathrm{mg}(n=8)$ tadalafil (Ghofrani et al. 2004). Hemodynamics and gas exchange responses were assessed over a subsequent 120 min observation period. All three PDE-5 inhibitors caused significant pulmonary vasorelaxation, accompanied by an increase of cardiac output, with maximum effects obtained after 40-45 min (vardenafil), $60 \mathrm{~min}$ (sildenafil), and 75-90 min (tadalafil). Sildenafil and tadalafil, but not vardenafil, caused a significant reduction of the pulmonary to systemic vascular resistance ratio. Significant improvement in systemic arterial oxygenation, corresponding to that observed during NO inhalation, was noted only with sildenafil. Thus, the three PDE-5 inhibitors appeared to differ in their kinetics of pulmonary vasorelaxation (most rapid effect produced by vardenafil), selectivity for the pulmonary circulation (sildenafil and tadalafil, but not vardenafil), and impact on systemic arterial oxygenation (improvement only after sildenafil). A controlled clinical trial investigating the effects of the PDE5 inhibitor tadalafil in patients with PAH has recently come to an end (LVGY and LVGX); the results will be released in late 2008. 


\section{Soluble Guanylate Cyclase: A New Target for the Treatment of Pulmonary Vascular Disorders}

The downstream effector of NO is the enzyme soluble guanylate cyclase (sGC), which synthesizes the second messenger cyclic guanosine monophosphate (cGMP). Soluble GC is typically found as a heterodimer, consisting of a larger $\alpha$-subunit and a smaller haem-binding $\beta$-subunit. The binding of NO to sGC results in activation and synthesis of the second messenger cGMP. Further, cGMP activates cGMP-dependent protein kinases (PKGs), leading to a reduction of cytosolic $\mathrm{Ca}^{2+}$ concentration and desensitization of the actin-myosin contractile system. Although impairment of the endothelium-dependent regulation of pulmonary vascular tone is consistently reported, the analysis of the role of $\mathrm{sGC}$ in chronic hypoxia-induced PAH has yielded conflicting data, with both increases and decreases of sGC protein expression described (Hassoun et al. 2004; Li et al. 2001; Li et al. 1999). Therapeutic potential has been reported for $\mathrm{YC}-1$, which acts as an "NO-sensitizer," greatly enhancing the sensitivity of sGC towards NO (Friebe and Koesling 1998; Friebe et al. 1996). YC-1 increases cGMP in smooth muscle cells and induces a dosedependent vasodilation of endothelium-denuded rat aortic rings (Mulsch et al. 1997; Wegener and Nawrath 1997; Galle et al. 1999). Furthermore, YC-1 has been shown to inhibit the adhesion and aggregation of platelets (Teng et al. 1997; Wu et al. 1995; Friebe et al. 1998). Recently, the compound Bay 41-2272, which stimulates sGC directly and enhances the sensitivity of sGC to NO, was shown to be a systemic and pulmonary vasodilator (Stasch et al. 2001; Boerrigter et al. 2003). Furthermore, it augments the vasodilator response to inhaled NO when acute pulmonary hypertension is produced in lambs (Evgenov et al. 2004). While Bay 41-2272 activates sGC in its native form, another compound, Bay 58-2667, has recently been shown to activate $\mathrm{sGC}$ even in its oxidized or heme-free form and independent of the activity of nitric oxide (Stasch et al. 2002). In animal models of pulmonary hypertension, it was demonstrated that both the soluble guanylate cyclase stimulator Bay 41-2272 and the soluble guanylate cyclase activator Bay 58-2667 reverse pulmonary hypertension in chronically hypoxic mice and monocrotaline-injected rats. Notably, treatment with these agents was commenced only after full establishment of pulmonary hypertension and right heart hypertrophy, with structural changes in the lung's vasculature. The compound Bay 41-2272 is a novel NO-independent stimulator of sGC with similar characteristics to YC-1 (but with higher potency of about two to three orders of magnitude) and no PDE 5 inhibitory activity (Straub et al. 2001; Stasch et al. 2002). A deeper molecular understanding and encouraging pre-clinical results with stimulators and activators of sGC warranted further clinical development of compounds from this class for the treatment of pulmonary vascular disorders.

In a first clinical trial of patients with moderate-to-severe PH (pulmonary arterial hypertension, distal chronic thromboembolic $\mathrm{PH}$, or $\mathrm{PH}$ with mild to moderate interstitial lung disease), the safety, tolerability, and efficacy of the oral sGC stimulator BAY 63-2521 was evaluated. After the optimal tolerated dose was identified by initial patient studies, pharmacodynamic and pharmacokinetic parameters were assessed following a single dose administration $(2.5$ or $1 \mathrm{mg})$ in 19 patients. 


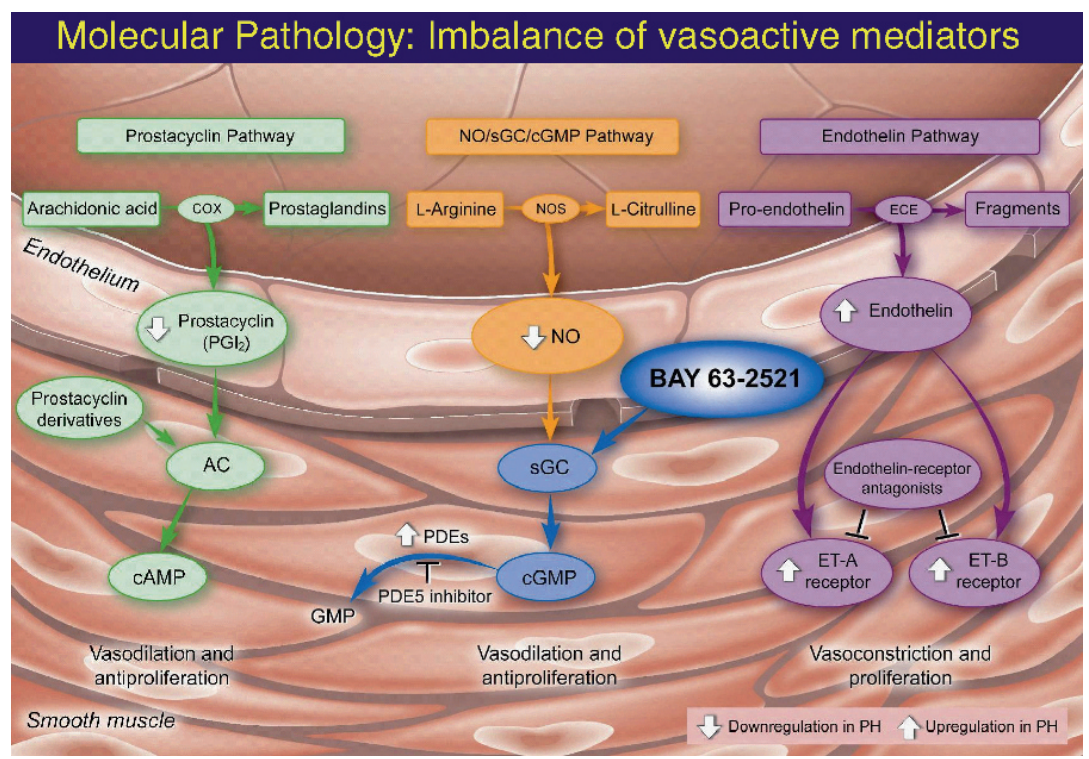

Fig. 6 Molecular pathology of pulmonary hypertension. The three major molecular pathways for pulmonary hypertension that are currently addressed by medical treatments are depicted in this picture. Prostacyclin is produced by prostacyclin synthase and activates the adenylate cyclase (AC), which produces the second messenger cAMP, leading to vasodilatation and antiproliferation. The NO pathway operates via activation of the sGC and elevation of cGMP, resulting in beneficial vasorelaxation and antiproliferation. Therapeutically this pathway can be addressed either by direct stimulation of the sGC, for example, with Bay 63-2521 or by administration of a PDE5 inhibitor. Lastly, the endothelin mediated effects of vasoconstriction and proliferation can be counteracted by the administration of endothelin receptor antagonists

In this short term trial, BAY 63-2521 had a favorable safety profile at a single dose $\leqslant 2.5 \mathrm{mg}$. It significantly improved all major hemodynamic parameters in patients with $\mathrm{PH}$ in a dose-dependent manner, to a greater extent than inhaled NO, while maintaining mean systolic blood pressure above $110 \mathrm{mmHg}$. These results supported the view that sGC stimulators may have potential as a novel therapy for $\mathrm{PH}$ and warranted further investigation. Recently, clinical phase II and III trials in chronic pulmonary hypertension have been initiated with these compounds. Provided the outcome of these trials is positive, chemical sGC activators and stimulators may soon find their way into the list of molecular targets for the treatment of pulmonary vascular disorders (Fig. 6).

\section{References}

Abrams D, Schulze-Neick I, Magee AG (2000) Sildenafil as a selective pulmonary vasodilator in childhood primary pulmonary hypertension. Heart 84:E4 
Agusti AG, Rodriguez-Roisin R (1993) Effect of pulmonary hypertension on gas exchange. Eur Respir J 6:1371-1377

Ahn HS, Foster M, Cable M, Pitts BJ, Sybertz EJ (1991) Ca/CaM-stimulated and cGMP-specific phosphodiesterases in vascular and non-vascular tissues. Adv Exp Med Biol 308:191-197

Beavo JA (1995) Cyclic nucleotide phosphodiesterases: functional implications of multiple isoforms. Physiol Rev 75:725-748

Boerrigter G, Costello-Boerrigter LC, Cataliotti A, Tsuruda T, Harty GJ, Lapp H, Stasch JP, Burnett JC Jr (2003) Cardiorenal and humoral properties of a novel direct soluble guanylate cyclase stimulator BAY 41-2272 in experimental congestive heart failure. Circulation 107: 686-689

Bohle RM, Hartmann E, Kinfe T, Ermert L, Seeger W, Fink L (2000) Cell type-specific mRNA quantitation in non-neoplastic tissues after laser-assisted cell picking. Pathobiology 68: 191-195

Carlsen J, Kjeldsen K, Gerstoft J (2002) Sildenafil as a successful treatment of otherwise fatal HIV-related pulmonary hypertension. AIDS 16:1568-1569

Channick RN, Newhart JW, Johnson FW, Williams PJ, Auger WR, Fedullo PF, Moser KM (1996) Pulsed delivery of inhaled nitric oxide to patients with primary pulmonary hypertension: an ambulatory delivery system and initial clinical tests. Chest 109:1545-1549

Cohen AH, Hanson K, Morris K, Fouty B, McMurty IF, Clarke W, Rodman DM (1996) Inhibition of cyclic $3^{\prime}-5^{\prime}$-guanosine monophosphate-specific phosphodiesterase selectively vasodilates the pulmonary circulation in chronically hypoxic rats. J Clin Invest 97:172-179

Corbin JD, Francis SH (2002) Pharmacology of phosphodiesterase-5 inhibitors. Int J Clin Pract $56: 453-459$

Egan JJ (1999) New treatments for pulmonary fibrosis? Lancet 354:1839-1840

Evgenov OV, Ichinose F, Evgenov NV, Gnoth MJ, Falkowski GE, Chang Y, Bloch KD, Zapol WM (2004) Soluble guanylate cyclase activator reverses acute pulmonary hypertension and augments the pulmonary vasodilator response to inhaled nitric oxide in awake lambs. Circulation 110:2253-2259

Francis SH, Chu DM, Thomas MK, Beasley A, Grimes K, Busch JL, Turko IV, Haik TL, Corbin JD (1998) Ligand-induced conformational changes in cyclic nucleotide phosphodiesterases and cyclic nucleotide-dependent protein kinases. Methods 14:81-92

Friebe A, Koesling D (1998) Mechanism of YC-1-induced activation of soluble guanylyl cyclase. Mol Pharmacol 53:123-127

Friebe A, Schultz G, Koesling D (1996) Sensitizing soluble guanylyl cyclase to become a highly CO-sensitive enzyme. EMBO J 15:6863-6868

Friebe A, Mullershausen F, Smolenski A, Walter U, Schultz G, Koesling D (1998) YC-1 potentiates nitric oxide- and carbon monoxide-induced cyclic GMP effects in human platelets. Mol Pharmacol 54:962-967

Galie N, Ghofrani HA, Torbicki A, Barst RJ, Rubin LJ, Badesch D, Fleming T, Parpia T, Burgess G, Branzi A, Grimminger F, Kurzyna M, Simonneau G (2005) Sildenafil citrate therapy for pulmonary arterial hypertension. N Engl J Med 353:2148-2157

Galle J, Zabel U, Hubner U, Hatzelmann A, Wagner B, Wanner C, Schmidt HH (1999) Effects of the soluble guanylyl cyclase activator, YC-1, on vascular tone, cyclic GMP levels and phosphodiesterase activity. Br J Pharmacol 127:195-203

German Z, Chambliss KL, Pace MC, Arnet UA, Lowenstein CJ, Shaul PW (2000) Molecular basis of cell-specific endothelial nitric-oxide synthase expression in airway epithelium. J Biol Chem 275:8183-8189

Ghofrani HA, Wiedemann R, Rose F, Olschewski H, Schermuly RT, Weissmann N, Seeger W, Grimminger F (2002a) Combination therapy with oral sildenafil and inhaled iloprost for severe pulmonary hypertension. Ann Intern Med 136:515-522

Ghofrani HA, Wiedemann R, Rose F, Schermuly RT, Olschewski H, Weissmann N, Gunther A, Walmrath D, Seeger W, Grimminger F (2002b) Sildenafil for treatment of lung fibrosis and pulmonary hypertension: a randomised controlled trial. Lancet 360:895-900 
Ghofrani HA, Rose F, Schermuly RT, Olschewski H, Wiedemann R, Kreckel A, Weissmann N, Ghofrani S, Enke B, Seeger W, Grimminger F (2003a) Oral sildenafil as long-term adjunct therapy to inhaled iloprost in severe pulmonary arterial hypertension. J Am Coll Cardiol 42: $158-164$

Ghofrani HA, Schermuly RT, Rose F, Wiedemann R, Kohstall MG, Kreckel A, Olschewski H, Weissmann N, Enke B, Ghofrani S, Seeger W, Grimminger F (2003b) Sildenafil for long-term treatment of nonoperable chronic thromboembolic pulmonary hypertension. Am J Respir Crit Care Med 167:1139-1141

Ghofrani HA, Voswinckel R, Reichenberger F, Olschewski H, Haredza P, Karadas B, Schermuly RT, Weissmann N, Seeger W, Grimminger F (2004) Differences in hemodynamic and oxygenation responses to three different phosphodiesterase-5 inhibitors in patients with pulmonary arterial hypertension: a randomized prospective study. J Am Coll Cardiol 44: $1488-1496$

Gopal VK, Francis SH, Corbin JD (2001) Allosteric sites of phosphodiesterase-5 (PDE5). A potential role in negative feedback regulation of cGMP signaling in corpus cavernosum. Eur $\mathrm{J}$ Biochem 268:3304-3312

Grimminger F, Spriestersbach R, Weissmann N, Walmrath D, Seeger W (1995) Nitric oxide generation and hypoxic vasoconstriction in buffer-perfused rabbit lungs. J Appl Physiol 78: $1509-1515$

Hassoun PM, Filippov G, Fogel M, Donaldson C, Kayyali US, Shimoda LA, Bloch KD (2004) Hypoxia decreases expression of soluble guanylate cyclase in cultured rat pulmonary artery smooth muscle cells. Am J Respir Cell Mol Biol 30:908-913

Higenbottam T, Siddons T, Demoncheaux E (2000) A therapeutic role for chronic inhaled nitric oxide? Lancet 356:446-447

Hillier SC, Graham JA, Hanger CC, Godbey PS, Glenny RW, Wagner WW Jr (1997) Hypoxic vasoconstriction in pulmonary arterioles and venules. J Appl Physiol 82:1084-1090

Hoeper MM, Schwarze M, Ehlerding S, Adler-Schuermeyer A, Spiekerkoetter E, Niedermeyer J, Hamm M, Fabel H (2000) Long-term treatment of primary pulmonary hypertension with aerosolized iloprost, a prostacyclin analogue. N Engl J Med 342:1866-1870

Huai Q, Liu Y, Francis SH, Corbin JD, Ke H (2004) Crystal structures of phosphodiesterases 4 and 5 in complex with inhibitor 3-isobutyl-1-methylxanthine suggest a conformation determinant of inhibitor selectivity. J Biol Chem 279:13095-13101

Ide H, Nakano H, Ogasa T, Osanai S, Kikuchi K, Iwamoto J (1999) Regulation of pulmonary circulation by alveolar oxygen tension via airway nitric oxide. J Appl Physiol 87:1629-1636

Kothari SS, Duggal B (2002) Chronic oral sildenafil therapy in severe pulmonary artery hypertension. Indian Heart J 54:404-409

Lepore JJ, Maroo A, Pereira NL, Ginns LC, Dec GW, Zapol WM, Bloch KD, Semigran MJ (2002) Effect of sildenafil on the acute pulmonary vasodilator response to inhaled nitric oxide in adults with primary pulmonary hypertension. Am J Cardiol 90:677-680

Li D, Zhou N, Johns RA (1999) Soluble guanylate cyclase gene expression and localization in rat lung after exposure to hypoxia. Am J Physiol 277:L841-L847

Li D, Laubach VE, Johns RA (2001) Upregulation of lung soluble guanylate cyclase during chronic hypoxia is prevented by deletion of eNOS Am J Physiol Lung Cell Mol Physiol 281: L369-L376

Melot C, Lejeune P, Leeman M, Moraine JJ, Naeije R (1989) Prostaglandin E1 in the adult respiratory distress syndrome. Benefit for pulmonary hypertension and cost for pulmonary gas exchange. Am Rev Respir Dis 139:106-110

Michelakis E, Tymchak W, Lien D, Webster L, Hashimoto K, Archer S (2002) Oral sildenafil is an effective and specific pulmonary vasodilator in patients with pulmonary arterial hypertension: comparison with inhaled nitric oxide. Circulation 105:2398-2403

Michelakis ED, Tymchak W, Noga M, Webster L, Wu XC, Lien D, Wang SH, Modry D, Archer SL (2003) Long-term treatment with oral sildenafil is safe and improves functional capacity and hemodynamics in patients with pulmonary arterial hypertension. Circulation 108:2066-2069 
Moncada I, Jara J, Subira D, Castano I, Hernandez C (2004) Efficacy of sildenafil citrate at 12 hours after dosing: re-exploring the therapeutic window. Eur Urol 46:357-360

Mullershausen F, Friebe A, Feil R, Thompson WJ, Hofmann F, Koesling D (2003) Direct activation of PDE5 by cGMP: long-term effects within NO/cGMP signaling. J Cell Biol 160:719-727

Mulsch A, Bauersachs J, Schafer A, Stasch JP, Kast R, Busse R (1997) Effect of YC-1, an NOindependent, superoxide-sensitive stimulator of soluble guanylyl cyclase, on smooth muscle responsiveness to nitrovasodilators. Br J Pharmacol 120:681-689

Oliver J, Webb DJ (2002) Sildenafil for "blue babies". Such unlicensed drug use might be justified as last resort. BMJ 325:1174

Olschewski H, Walmrath D, Schermuly R, Ghofrani A, Grimminger F, Seeger W (1996) Aerosolized prostacyclin and iloprost in severe pulmonary hypertension. Ann Intern Med 124:820-824

Olschewski H, Ghofrani HA, Walmrath D, Temmesfeld-Wollbruck B, Grimminger F, Seeger W (1998) Recovery from circulatory shock in severe primary pulmonary hypertension (PPH) with aerosolization of iloprost. Intensive Care Med 24:631-634

Olschewski H, Ghofrani HA, Walmrath D, Schermuly R, Temmesfeld-Wollbruck B, Grimminger F, Seeger W (1999) Inhaled prostacyclin and iloprost in severe pulmonary hypertension secondary to lung fibrosis. Am J Respir Crit Care Med 160:600-607

Olschewski H, Ghofrani HA, Schmehl T, Winkler J, Wilkens H, Hoper MM, Behr J, Kleber FX, Seeger W (2000) Inhaled iloprost to treat severe pulmonary hypertension. An uncontrolled trial. German PPH Study Group. Ann Intern Med 132:435-443

Olschewski H, Simonneau G, Galie N, Higenbottam T, Naeije R, Rubin LJ, Nikkho S, Speich R, Hoeper MM, Behr J, Winkler J, Sitbon O, Popov W, Ghofrani HA, Manes A, Kiely DG, Ewert R, Meyer A, Corris PA, Delcroix M, Gomez-Sanchez M, Siedentop H, Seeger W (2002) Inhaled iloprost for severe pulmonary hypertension. N Engl J Med 347:322-329

Patole S, Travadi J (2002) Sildenafil for "blue babies". Ethics, conscience, and science have to be balanced against limited resources. BMJ 325:1174

Prasad S, Wilkinson J, Gatzoulis MA (2000) Sildenafil in primary pulmonary hypertension. N Engl J Med 343:1342

Radermacher P, Santak B, Becker H, Falke KJ (1989) Prostaglandin E1 and nitroglycerin reduce pulmonary capillary pressure but worsen ventilation-perfusion distributions in patients with adult respiratory distress syndrome. Anesthesiology 70:601-606

Reichenberger F, Voswinckel R, Enke B, Rutsch M, Fechtali EE, Schmehl T, Olschewski H, Schermuly R, Weissmann N, Ghofrani HA, Grimminger F, Mayer E, Seeger W (2007) Longterm treatment with sildenafil in chronic thromboembolic pulmonary hypertension. Eur Respir J 30:922-927

Rossaint R, Falke KJ, Lopez F, Slama K, Pison U, Zapol WM (1993) Inhaled nitric oxide for the adult respiratory distress syndrome. N Engl J Med 328:399-405

Rubin LJ (1997) Primary pulmonary hypertension. N Engl J Med 336:111-117

Sastry BK, Narasimhan C, Reddy NK, Anand B, Prakash GS, Raju PR, Kumar DN (2002) A study of clinical efficacy of sildenafil in patients with primary pulmonary hypertension. Indian Heart $\mathbf{J}$ $54: 410-414$

Sastry BK, Narasimhan C, Reddy NK, Raju BS (2004) Clinical efficacy of sildenafil in primary pulmonary hypertension: a randomized, placebo-controlled, double-blind, crossover study. J Am Coll Cardiol 43:1149-1153

Schermuly RT, Roehl A, Weissmann N, Ghofrani HA, Schudt C, Tenor H, Grimminger F, Seeger W, Walmrath D (2000) Subthreshold doses of specific phosphodiesterase type 3 and 4 inhibitors enhance the pulmonary vasodilatory response to nebulized prostacyclin with improvement in gas exchange. J Pharmacol Exp Ther 292:512-520

Schumacher YO, Zdebik A, Huonker M, Kreisel W (2001) Sildenafil in HIV-related pulmonary hypertension. AIDS 15:1747-1748

Singh B, Gupta R, Punj V, Ghose T, Sapra R, Grover DN, Kaul U (2002) Sildenafil in the management of primary pulmonary hypertension. Indian Heart J 54:297-300 
Stasch JP, Becker EM, onso-Alija C, Apeler H, Dembowsky K, Feurer A, Gerzer R, Minuth T, Perzborn E, Pleiss U, Schroder H, Schroeder W, Stahl E, Steinke W, Straub A, Schramm M (2001) NO-independent regulatory site on soluble guanylate cyclase. Nature 410:212-215

Stasch JP, Schmidt P, onso-Alija C, Apeler H, Dembowsky K, Haerter M, Heil M, Minuth T, Perzborn E, Pleiss U, Schramm M, Schroeder W, Schroder H, Stahl E, Steinke W, Wunder F (2002) NO- and haem-independent activation of soluble guanylyl cyclase: molecular basis and cardiovascular implications of a new pharmacological principle. Br J Pharmacol 136:773-783

Straub A, Stasch JP, onso-Alija C, et-Buchholz J, Ducke B, Feurer A, Furstner C (2001) NOindependent stimulators of soluble guanylate cyclase. Bioorg Med Chem Lett 11:781-784

Teng CM, Wu CC, Ko FN, Lee FY, Kuo SC (1997) YC-1, a nitric oxide-independent activator of soluble guanylate cyclase, inhibits platelet-rich thrombosis in mice. Eur J Pharmacol 320: $161-166$

Von Euler US, Liljestrand G (1946) Observations on the pulmonary arterial blood pressure in the cat. Acta Physiol Scand 12:301-320

Walmrath D, Schneider T, Pilch J, Grimminger F, Seeger W (1993) Aerosolised prostacyclin in adult respiratory distress syndrome. Lancet 342:961-962

Watanabe H, Ohashi K, Takeuchi K, Yamashita K, Yokoyama T, Tran QK, Satoh H, Terada H, Ohashi H, Hayashi H (2002) Sildenafil for primary and secondary pulmonary hypertension. Clin Pharmacol Ther 71:398-402

Wegener JW, Nawrath H (1997) Differential effects of isoliquiritigenin and YC-1 in rat aortic smooth muscle. Eur J Pharmacol 323:89-91

Weissmann N, Voswinckel R, Tadic A, Hardebusch T, Ghofrani HA, Schermuly RT, Seeger W, Grimminger F (2000) Nitric oxide (NO)-dependent but not NO-independent guanylate cyclase activation attenuates hypoxic vasoconstriction in rabbit lungs. Am J Respir Cell Mol Biol 23:222-227

Weissmann N, Grimminger F, Olschewski A, Seeger W (2001) Hypoxic pulmonary vasoconstriction: a multifactorial response? Am J Physiol Lung Cell Mol Physiol 281:L314-L317

Wilkens H, Guth A, Konig J, Forestier N, Cremers B, Hennen B, Bohm M, Sybrecht GW (2001) Effect of inhaled iloprost plus oral sildenafil in patients with primary pulmonary hypertension. Circulation 104:1218-1222

Wu CC, Ko FN, Kuo SC, Lee FY, Teng CM (1995) YC-1 inhibited human platelet aggregation through NO-independent activation of soluble guanylate cyclase. $\mathrm{Br} \mathrm{J}$ Pharmacol 116: 1973-1978

Zhao L, Mason NA, Strange JW, Walker H, Wilkins MR (2003) Beneficial effects of phosphodiesterase 5 inhibition in pulmonary hypertension are influenced by natriuretic Peptide activity. Circulation 107:234-237

Zimmermann AT, Calvert AF, Veitch EM (2002) Sildenafil improves right-ventricular parameters and quality of life in primary pulmonary hypertension. Intern Med J 32:424-426 